\title{
Competition in a mixed-species planting with four contrasting species
}

\author{
Jerome K Vanclay ${ }^{1,2 *}$, Nestor Gregorio², John L. Herbohn ${ }^{2}$ \\ 1. Southern Cross University, Australia \\ 2. University of the Sunshine Coast, Australia \\ * Corresponding author: jvanclay@scu.edu.au
}

\begin{abstract}
Background: Mixed-species systems are well-suited to smallholder and community forestry, but reliable evidence regarding and procedures to assess species performance in such systems is scarce. This study concern a field trial with a pair of clinal plots varying spacing and species composition that offered insights into competition between four species proposed for mixed-species plantings by smallholders for landscape rehabilitation in the Philippines.

Results: Use of a size-distance competition index allowed an assessment of the competitive and collaborative influences between four tree species. Within the expected general trend for growth to decline with increasing competition, there were indications that Shorea palosapis is a benign competitor that may stimulate the growth of neighbouring individuals. Paraserianthes falcataria is a strong competitor that is also strongly impacted by competition, especially through antagonistic intraspecific competition. Paraserianthes falcataria appears well suited as a solitary tree in a field or village, whereas Shorea palosapis seems ideal for plantations, in both monoculture and mixed plantings.
\end{abstract}

Conclusion: Pterocarpus indicus exbibits strong intraspecific, but low inter-specific competition, so appears well-suited for polyculture plantings. Of the four species, Swietenia macrophylla appears to be best-suited as a monoculture species as it exhibits the lowest intraspecific competition.

Keywords: Paraserianthes falcataria, Pterocarpus indicus, Shorea palosapis, Swietenia macrophylla, polyculture, clinal experiment, forest landscape restoration

\section{Introduction}

In recent years here has been increasing interest in mixed-species plantings to establish plantations that provide multiple services in the tropics (Kelty 2006, Nguyen et al 2015). The proportion of new plantings which are mixtures however is low, and Nichols et al (2006) has estimated that mixtures comprise less than 0.1 of industrial plantations worldwide. This is in part due to mixed-species plantations being much more complex to establish and manage due to limited knowledge of these systems (Dickinson 2008), including a lack of knowledge concerning species selection and sitematching (Manson et al 2013, Trogisch et al 2021).

In a systematic review of the available evidence related to the performance of mixed-species plantings, Nguyen et al (2018) found that most studies focused on the effects of species mixtures on stand production or ecological functioning relative to that in monocultures (i.e. 167 studies 
comprising $72 \%$ of biophysical studies identified). In contrast, very few studies $(n=29)$ investigated interactions or competition between species. Fundamental to designing mixed-species stands is to include species that are complementary, for instance with a range of traits such as shade tolerance, height growth rate, crown structure and root depth (e.g. Lui et al 2018).

Mixed-species systems are well-suited to smallholder and community forestry (Chechina \& Hamann 2015). This is particularly so for situations where smallholders rely on forests for multiple products in support of their livelihood strategies. Similarly, mixed species systems are also well suited to forest and landscape restoration initiatives undertaken as part of the Bonn Challenge and similar international commitments to reforestation. In particular, many of these initiatives will be achieved through some form of community or smallholder forestry using mixtures of species. There is also an increasing desire by implementing agencies and local stakeholders to use species native to the areas being restored.

In the case of the Philippines, the National Greening Program (Goltiano et al 2021) is a substantial reforestation initiative that commenced in 2011 and was renewed in 2016 with a commitment to reforest 7 million hectares. Much of the plantings have been mixtures of native and exotic species, and biodiversity restoration is one of the four goals of the program. There has been however little evidence on which to base the selection of species and the way that species are combined. In particular, information is needed on what species are best suited for inclusion in diverse mixtures and conversely, what species should be avoided. While there is undoubtedly some knowledge about species performance, little formal literature has been published on both the performance of native species and the species that grow (or don't grow) well together. The species have been largely ad hoc mixtures of whatever planting stock is available at the time of planting.

Previous research on mixed-species plantations in the Philippines has revealed that results indicate that mixtures of fast-growing exotics species had better growth performance compared to monocultures of fast-growing exotics species, and also better tree species diversity performance at both the plot and landscape scale (Le et al 2020). Mixed species plantations in the Philippines are dynamic systems. Nguyen et al (2014a) found that over time shade-intolerant species became less important and native shade-tolerant species (often Dipterocarps) increasing in importance, with at least part of this change being driven by anthropogenic influences such as harvesting of fast-growing exotic species. Despite the widespread use of mixtures within the National Greening Program, there is little guidance as to the basis on which to design mixtures. The only substantive attempt has been by Nguyen et al (2014b) who found that wood density offered some potential to identify complementary species for the design of mixed species plantations. Several other studies have reported growth performance of individual native and exotic species grown in mixtures (Herbohn et al 2014, Nguyen et al 2016, Schneider et al 2014) and the stand productivity of mixed-species planting (e.g. Nguyen et al 2012, Veridiano et al 2020, Le et al 2021) However none of these studies presented any analysis about the impacts of individual species interactions on growth or productivity.

Provision of suitable data (Vanclay 1991, Vanclay et al 1995) remains an obstacle to the development of models to support forest landscape restoration, although robust models for datapoor situations are emerging (Vanclay 2010, 2017). This study draws on earlier work (Vanclay et al 2013) to evaluate competition in four species that are potential candidates for both smallholder plantations and forest landscape restoration. Practical constraints precluded a large comprehensive trial, and the current study deals with a compact design to shed light on preconceptions regarding the utility of four indigenous and nitrogen-fixing species in landscape restoration. 


\section{Methods}

Prior work with mixed-species plantings has revealed important interactions between nitrogen-fixing and other species (e.g., Forrester et al 2006), and this influenced our decision to create a contrast between nitrogen-fixing and non-leguminous trees, and between exotic and native species. Species selection was guided by the popularity of species in smallholder tree farming and reforestation programs in the Philippines (Gregorio et al 2020, Le et al 2021), and by the preferences of the landowner where the trial was established. The final choice was also partly influenced by the availability of seedlings suited to the site. The species ultimately included Falcata (Paraserianthes falcataria), Mahogany (Swietenia macrophylla), Narra (Pterocarpus indicus) and Mayapis (Shorea palosapis). Nursery and establishment techniques for these species are well established (e.g., Gregorio et al 2009, 2012).

The trial is located in the Sambulawon community near Leyte township in the eastern Philippines, approximately $11^{\circ} 22^{\prime} \mathrm{N} 124^{\circ} 30^{\prime} \mathrm{E}$ and $20 \mathrm{~m}$ above sea level. The field trial site is part of a longestablished hacienda, and had been cropped with sugarcane for many years until the 1970s. During the five years before the trial was commenced, the site was used for livestock grazing by the local community. The site was covered predominantly with grasses including Chrysopogon aciculatus, Axonopus compressus and Saccharum spontaneum, and included patches of the invasive weeds Chromolaena odorata and Lantana camara. The soil is a volcanic clay loam with pH 5.7. Soil organic matter and nitrogen content were $2.3 \%$ and $0.15 \%$ respectively, and extractable phosphorus was $1.3 \mathrm{mg} \mathrm{kg}^{-1}$.

The trial used high quality seedlings (Gregorio et al 2015, 2017) propagated in the nursery of ACIAR Project ASEM/2006/091 in Visayas State University. Weed control was minimal and limited to brushed lines, because we wished to examine likely performance of these species in smallholder and restoration situations where herbicides are not used (Fig. 1).

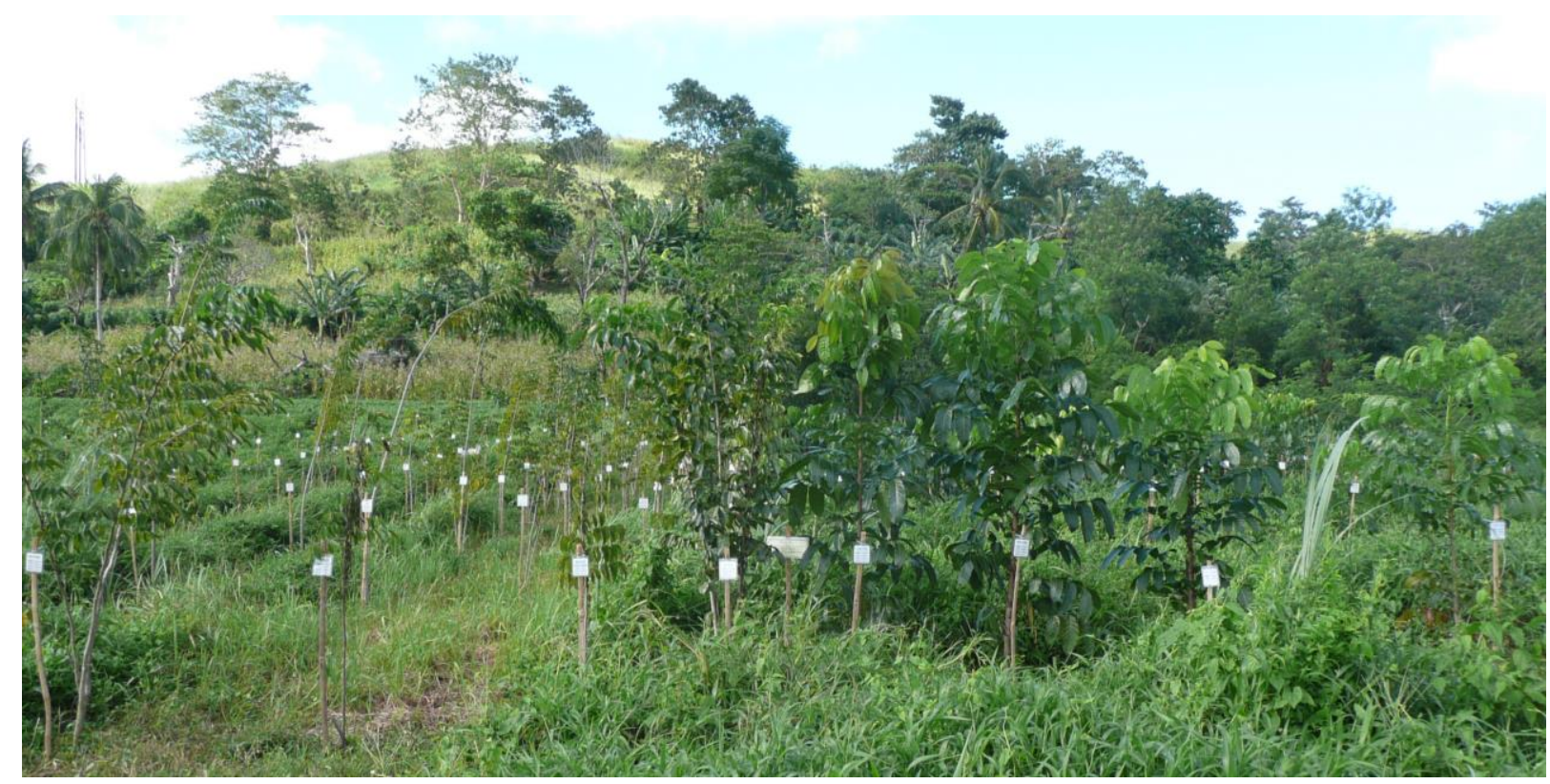

Figure 1. The variable spacing plot at 11 months old (November 2008), with Mahogany (S. macrophylla) in the right foreground, Narra (P. indicus) on left, and Falcata (P. falcataria) in the background. 
The seedlings were planted in December 2007 (Herbohn et al 2009) and measured on 15 occasions at 3-month (until 2010), 6-month (2010-12) or annual intervals (2012-13). The plots were badly damaged during Typhoon Haiyan (also known as Typhoon Yolanda, 7-8 November 2013), and this paper draws only on data collected prior to the typhoon. Nine of the 15 measurements were selected to provide regular observations at approximately 6-month intervals $(07 / 2008,01 / 2009$, 08/2009, 02/2010, 09/2010, 03/2011, 09/2011, 04/2012, 04/2013), resulting in eight intervals for the computation of diameter increment.

The trial was established using a paired clinal design (Vanclay 2006a) created to evaluate the performance both of mixtures at a standard spacing $(3 \times 3 \mathrm{~m})$, and of a monoculture with a variable spacing (from 0.6 to $7.5 \mathrm{~m}$; Figures $2 \& 3$ ).

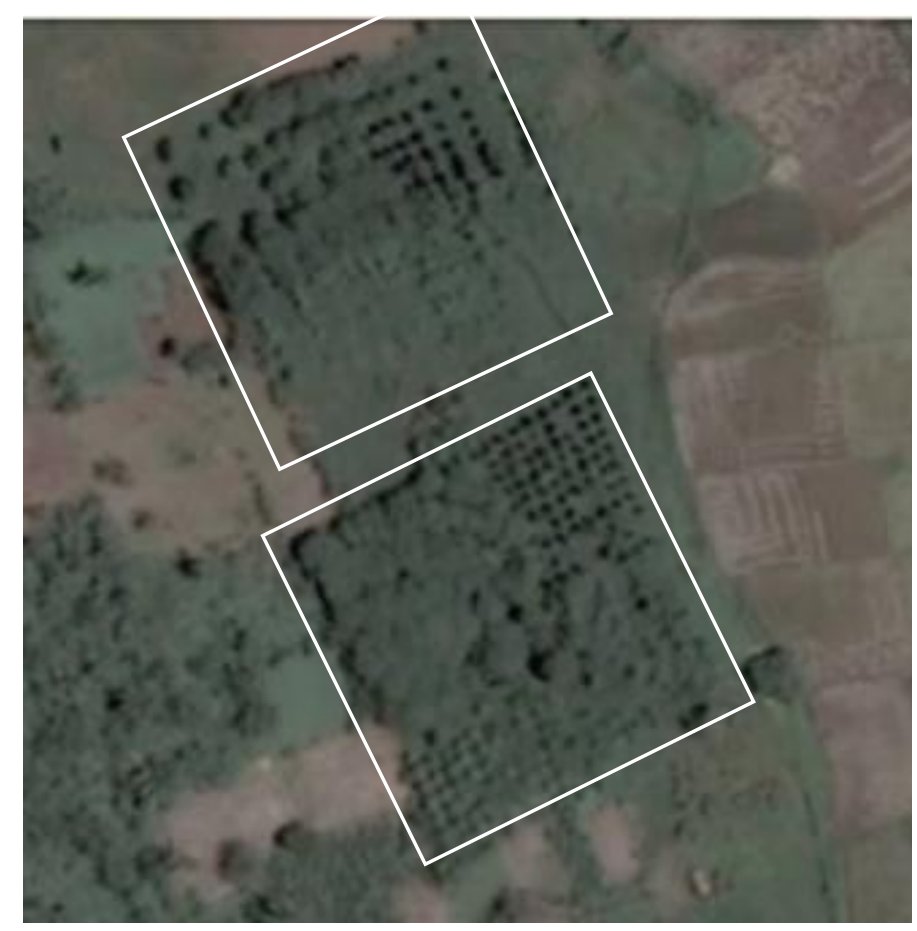

Figure 2. Google Earth image of the trail plots (4 July 2011). 


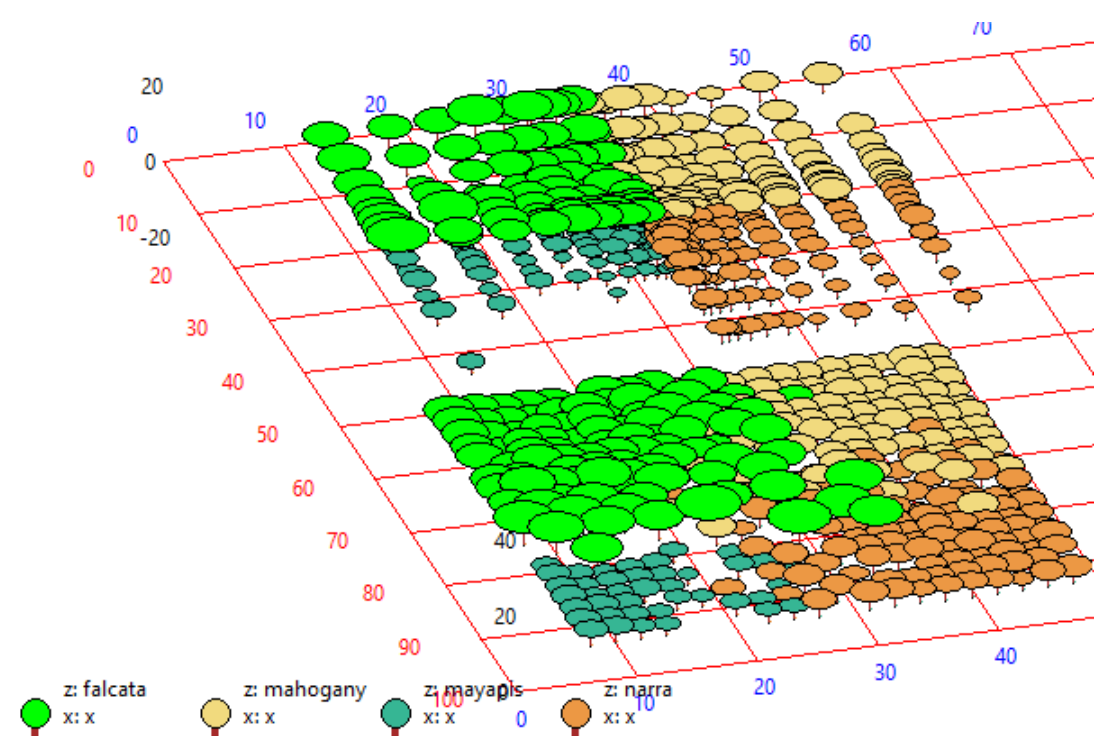

Figure 3. Diagram of the trial, viewed from the south and looking northwards (for comparison with Fig. 2), with the variable spacing plot at the top, and the variable composition plot at the bottom. Symbol size reflects DBH of the trees at age 3 (in 2010).

\section{Analysis}

This experiment sought to reveal growth patterns in stands planted with different proportions of species, and at different spacings. Thus the analysis investigated the response of diameter increment under this wide range of treatments (Fig. 3). In forest modelling, there is a long tradition of using a modifier function to reduce potential growth to account for suboptimal conditions (e.g., Botkin et al 1972, Ek \& Monserud 1974), but this approach requires an independent estimate of the potential growth, unavailable in the current study. A more flexible approach used in the present study is to estimate growth (e.g., diameter increment) directly from tree characteristics (e.g., species, size) and competition: $\Delta D=f$ (tree, competition). Ideally, this competition should be represented as a single variable, to facilitate comparisons between species.

The competition neighbourhood was calculated following Vanclay (2006b), using a search radius of $40 \times D$ and estimating competition following Hegyi (1974) as $\Sigma_{\mathrm{i}}\left\{\left(d_{\mathrm{i}} / d_{\mathrm{j}}\right) / D_{\mathrm{ij}}\right\}^{0.5}$ for all $D_{\mathrm{ij}}<0.4\left(d_{\mathrm{i}}+d_{\mathrm{j}}\right)$ where $D_{i j}$ is the distance between trees $i$ and $j, d$ is their observed tree diameter $(\mathrm{cm})$, calculated as a partial sum for each species combination of all perpetrators $i$ seen by victim $j$. Previous studies (Vanclay et al 2013) have shown that this competition index can exhibit a simple linear relationship with diameter increment, and this same linear trend is evident in the present data (Figure 4). 


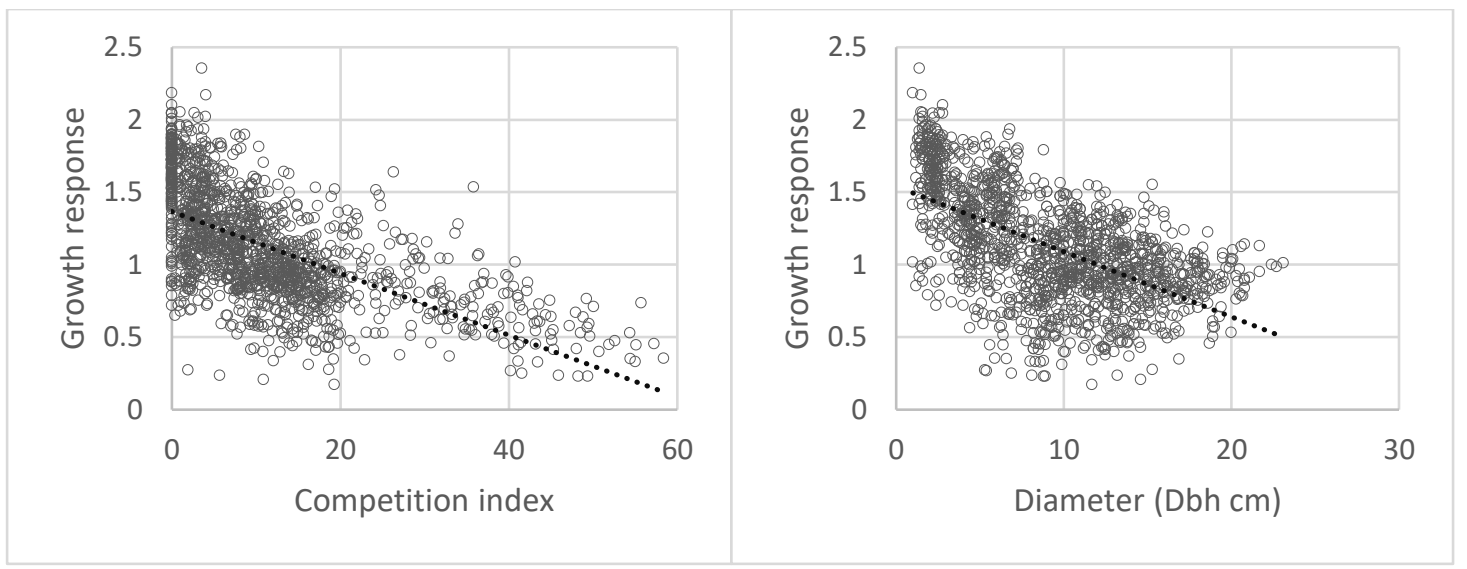

Figure 4. Linear trends between mahogany ( $S$. macrophylla) growth response and competition ( $4 a$, left) and diameter ( $4 b$, right)

Preliminary investigation of the untransformed data revealed that the relationship between increment and competition departed from the ideal linear relationship, so graphical analyses (Becker and Cleveland 1987, Cook and Weisberg 1999) were central to this analysis, assisting the search to find a suitable transformation to express competition as a single variable for each species. Inspection revealed that a variant of relative growth $\left(\triangle D / D^{0.5}\right)$ resulted in a linear relationship with competition for each of the four species (Figure 4). A Box-Cox (1964) analysis indicated tht a square-root transformation was required to stabilize variance, so subsequent analyses focused on the relationship $\left(\Delta D / D^{0.5}\right)^{0.5}=f($ species, size, competition):

$$
\left(\Delta D / D^{0.5}\right)^{0.5}=\alpha_{\mathrm{i}}+\gamma_{\mathrm{i}} D+\beta_{\mathrm{ij}} C_{\mathrm{j}}
$$

Eqn 1

where $D$ is tree diameter (dbhob, $\mathrm{cm}$ ), $C_{\mathrm{j}}$ is competition caused by species $\mathrm{j}$, and $\alpha, \gamma, \beta$ are parameters to be estimated. The parameter estimates are given in Table 1, and the Analysis of Variance is given in Table 2. The large influence of Falcata, both in the slope of the relationships (Table 1), and in the proportion of the variance explained (Table 2), is noteworthy.

Table 1. Parameter estimates for Equation1.

\begin{tabular}{|l|cc|cccc|}
\hline Species & Intercept & Diameter & \multicolumn{4}{|c|}{ Competition caused by $\beta_{i}$} \\
& $\alpha_{i}$ & $\gamma_{i}$ & Mayapis & Narra & Mahogany & Falcata \\
\hline Mayapis & 1.2835 & $-0.00779^{*}$ & $-0.00982^{\text {ns }}$ & $+0.01364^{\text {ns }}$ & $-0.01744^{\text {ns }}$ & +0.04766 \\
Narra & 1.1374 & -0.01185 & -0.01535 & -0.02730 & $-0.00709^{\text {ns }}$ & $+0.00908^{\text {ns }}$ \\
Mahogany & 1.5907 & -0.03541 & $-0.00098^{\text {ns }}$ & $-0.00690^{* *}$ & -0.00748 & -0.01291 \\
Falcata & 1.8174 & -0.02786 & -0.01172 & -0.01464 & -0.02716 & -0.05037 \\
\hline
\end{tabular}

All estimates significant at $\mathrm{P}<0.001$, except where superscript indicates $\mathrm{ns}>0.05,{ }^{*}<0.05,{ }^{* *}<0.01$ 
Table 2. Analysis of Variance for fit displayed in Table 1.

\begin{tabular}{|llllll|}
\hline Source & \multicolumn{1}{c}{$\mathrm{df}$} & \multicolumn{1}{c}{ SS } & \multicolumn{1}{c}{ MS } & \multicolumn{1}{c|}{$\mathrm{F}$} & p-value \\
\hline Regression & 23 & 440.70 & 19.161 & 185.2 & $<0.001$ \\
Intercept & 3 & 88.32 & 29.441 & 276.7 & $<0.001$ \\
Spp*Dbh & 4 & 77.52 & 19.381 & 182.2 & $<0.001$ \\
Spp*C $_{\text {mayapis }}$ & 4 & 8.39 & 2.097 & 19.7 & $<0.001$ \\
Spp*C $_{\text {narra }}$ & 4 & 12.61 & 3.152 & 29.6 & $<0.001$ \\
Spp*C $_{\text {mahogany }}$ & 4 & 3.45 & 0.863 & 8.1 & $<0.001$ \\
Spp*C $_{\text {falcata }}$ & 4 & 114.48 & 28.620 & 269.0 & $<0.001$ \\
Residual & 5458 & 564.68 & 0.103 & & \\
\hline Lack of fit & 4881 & 484.80 & 0.099 & 0.7 & 1.000 \\
Pure Error & 577 & 79.88 & 0.138 & & \\
\hline
\end{tabular}

Spp*Dbh indicates that a separate parameter is estimated for each species (i.e., the slope of the growth-size trend can vary by species). Spp*Cfalcata is the competition caused by Falcata, with different estimates for each of the 4 victims.

Figure 5 illustrates the growth pattern implied by this relationship. This relationship is consistent with several classic growth equations (e.g. Bertalanffy 1949; Zeide 1993), but requires fewer parameters, and is thus better suited to present data with its limited age range (0-6 years).

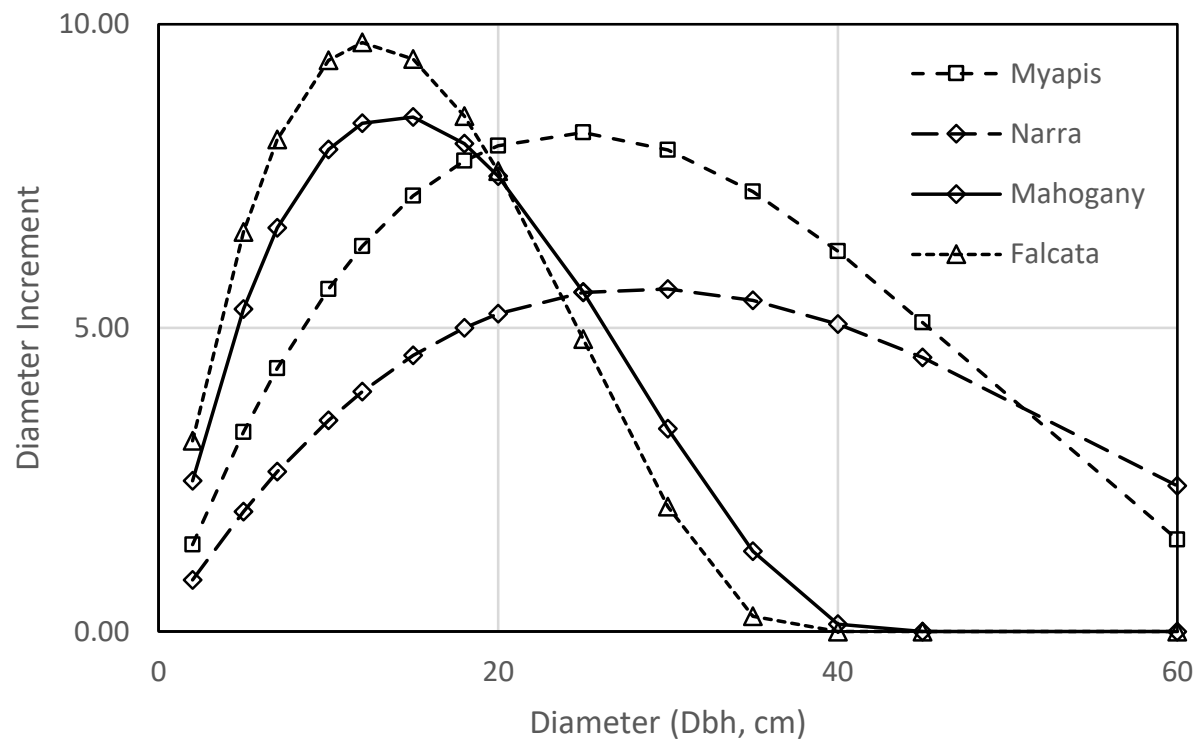

Figure 5. Pattern of diameter increment ( $\mathrm{dbh}, \mathrm{cm} / \mathrm{yr}$ ) implied by Equation 1 . The increment rate is strongly influenced by the amount of competition, and the maximum diameter is determined by the coefficient for diameter (Fig 4b).

In Figure 5, it is evident that the maximum attainable diameter of Mahogany and Falcata (45 and 65 $\mathrm{cm} \mathrm{dbh}$ respectively) are underestimated. This analysis was not aimed at a diameter increment function or at determining the maximum diameter, and these estimates arise from examining the adequacy of Equation 1 and its fit to the data. Equation 1 was aimed at revealing competition effects presented in Tables 1 and 2, and the implications revealed in Figure 5 simply examine possible 
shortcomings of the experimental design and analysis. Figure 6 shows a 2-dimensional surface fitted to the increment-size-competition data illustrating how the Mahogany data emphasise size (the surface appears near-vertical) and Narra data emphasise competition (the surface appears nearhorizontal). This it appears that the regression of Equation 1 apportions the decline in growth rate primarily to competition in Narra, and to tree size in Mahogany. A possible consequence of this that the competition effect may be underestimated, and the size effect overestimated for Mahogany and Falcata data (and as a result, the maximum size may be underestimated). This appears to be related to multicollinearity, even though (at $r=0.39$ for Mahogany) this is well below the usual cautionary thresholds for multicollinearity (Mansfield \& Helms 1982). It appears that natural mortality (unrelated to competition between trees) amongst Narra and Mayapis trees has reduced this effect and allowed a better estimate of the maximum diameter.

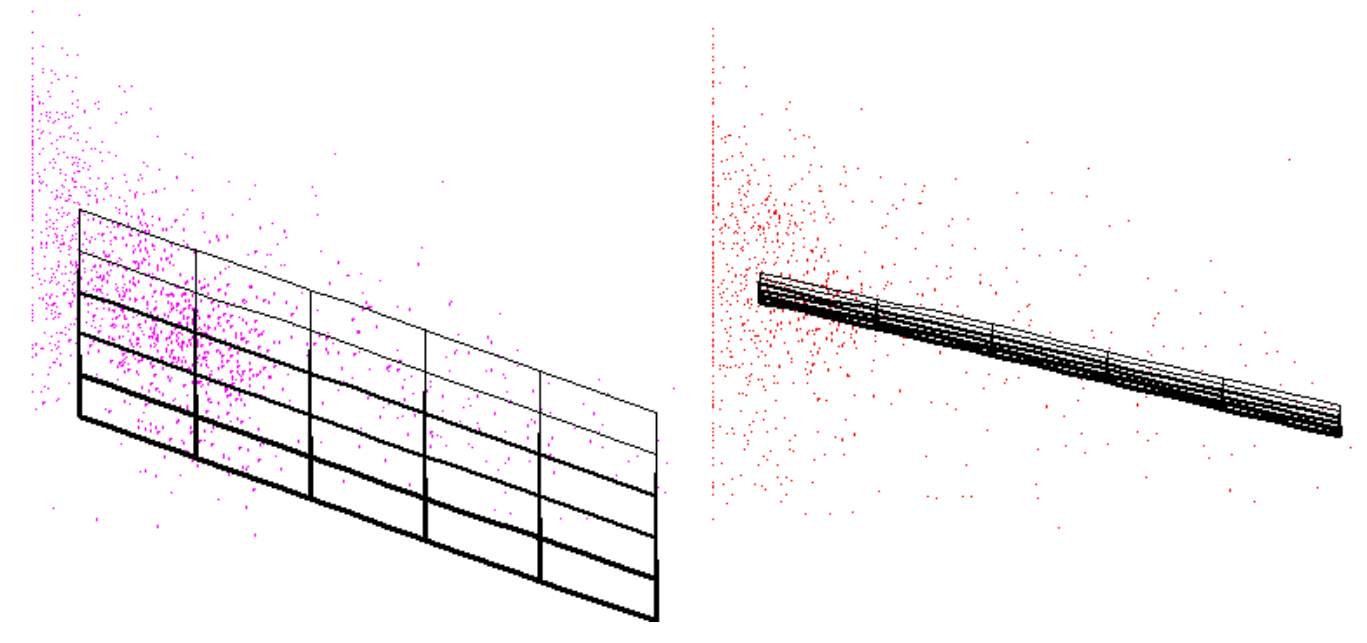

Figure 6. Three-dimensional graphs showing relative increment $\left(\Delta D / D^{0.5}\right)^{0.5}(Y$-axis), aggregate competition (X-axis), and tree size (outwards; larger symbol and thicker lines are closer to the viewer), with a 2-dimensional surface fitted for Mahogany (left) and Narra (right), showing how the present data indicate an emphasis on diameter in Mahogany and on competition in Narra.

\section{Results}

Competition may be viewed as an interaction between a perpetrator and victim, and Table 3 summarizes (from Table 1) such a view for each of our four species. Entries have been rounded deliberately to one significant digit to focus attention on major trends rather than minutiae, as competition responses may vary with environmental conditions (such as site and weather). Grey text indicates estimates that may be unreliable due to the small number of adjacencies between these species (and are not significantly different $\mathrm{P}>0.05$ from zero or from the overall response). Note that a positive entry in Table 3 does not necessarily imply a direct benefit by the perpetrator - there may be an indirect benefit such as shade, or suppression of grass (or other unquantified competition). 
Table 3. The slope of the growth-versus-competition trendline.

\begin{tabular}{|l|llll|l|}
\hline \multirow{2}{*}{ Victim } & \multicolumn{3}{|l|}{ Cause of competition (i.e., perpetrator) } & \multirow{2}{*}{ All } \\
& Mayapis & Narra & Mahogany & Falcata & perpetrators \\
\cline { 2 - 5 } Narra & -1 & +1 & -2 & +5 & -1 \\
Mahogany & -2 & -3 & -1 & +1 & -1 \\
Falcata & -1 & -1 & -1 & -1 & -2 \\
\hline All victims & +3 & -1 & -3 & -5 & -2 \\
\hline
\end{tabular}

The most aggressive interactions are highlighted in yellow; the most benign in green, and potential polyculture candidates are highlighted in blue.

In Table 3, the rightmost column indicates the expected trend (across all competing species) in which increasing competition reduces relative growth, but the bottom row reveals that Mayapis (S. palosapis) is not only benign, but may assist the growth of neighbouring individuals $(+3, P<0.001)$. Falcata ( $P$. falcataria) is noteworthy as it is not only a strong competitor $(-2, \mathrm{P}<0.001$, rightmost column), but is also strongly impacted by competition $(-3, P<0.001$, bottom row), and has antagonistic intraspecific competition $(-5, \mathrm{P}<0.001)$. Mayapis (S. palosapis) is a contrast, with a high tolerance for competition $(-1, \mathrm{P}<0.001$, rightmost column), and a tendency to stimulate the growth of its neighbours $(+3, P<0.001$, bottom row), and exhibiting modest intraspecific competition in monocultures $(-1, n s)$. Mayapis appears to benefit from Falcata $(+5, p<0.001)$, perhaps due to beneficial shading (Gregorio et al 2012). It would appear that Falcata is best suited as a solitary tree in a field or village, whereas Mayapis (S. palosapis) seems well suited to plantations, both monoculture and mixed plantings. Of the four species, Mahogany (S. macrophylla) appears to be the preferred monoculture species as it has the lowest intraspecific competition $(-1, \mathrm{P}=0.001)$.

Narra ( $P$. indicus) would appear to be an ideal polyculture species, as Table 1 reveals Narra to be tolerant of competition (the horizontal row in Table 3 has small or positive numbers), and to exhibit little impact on neighbours (the vertical column has small numbers). Table 1 suggests that combinations of Narra and Mayapis (S. palosapis), or Narra and Falcata (P. falcataria) could be successful. There is a hint that Narra may benefit Mayapis $(+1, P=0.2)$, and some evidence that Narra is benign towards Falcata $(-1, P=0.01)$. Even if direct benefit remains unconfirmed, an 'invisible' neighbour is preferable to a competitor, and indicates potential for a polyculture.

\section{Discussion}

Several measures can be used to compare growth performance: diameter, height, volume or biomass can all be used, and all have merits. In this study, diameter increment is preferred, as diameter is the most direct, accessible and reliable measure of tree size, and because the use of increment (rather than diameter) avoids serial correlation (Vanclay 1994) and thus better satisfies conventional statistical assumptions.

Linear regression was used to estimate the slope of the relationship between modelled competition and observed relative increment. Our analysis draws entirely on diameter (at $1.3 \mathrm{~m}$ breast height, over bark) and competition index because these are well-established as major determinants of stand performance (Potvin \& Dutilleul 2009, Forrester et al 2017), and were empirically identified in our data as the major determinants of stand development. We relied on a linear model of increment versus size and competition to focus attention on competition, noting that this explained a large proportion of the variance $(r=0.66, P<0.001)$, and that trends remained consistent when alternative 
models were examined. The use of relative growth rather than tree size as the dependent variable minimizes serial correlation, which is not problematic in this analysis (Durbin Watson statistic 1.83, ns).

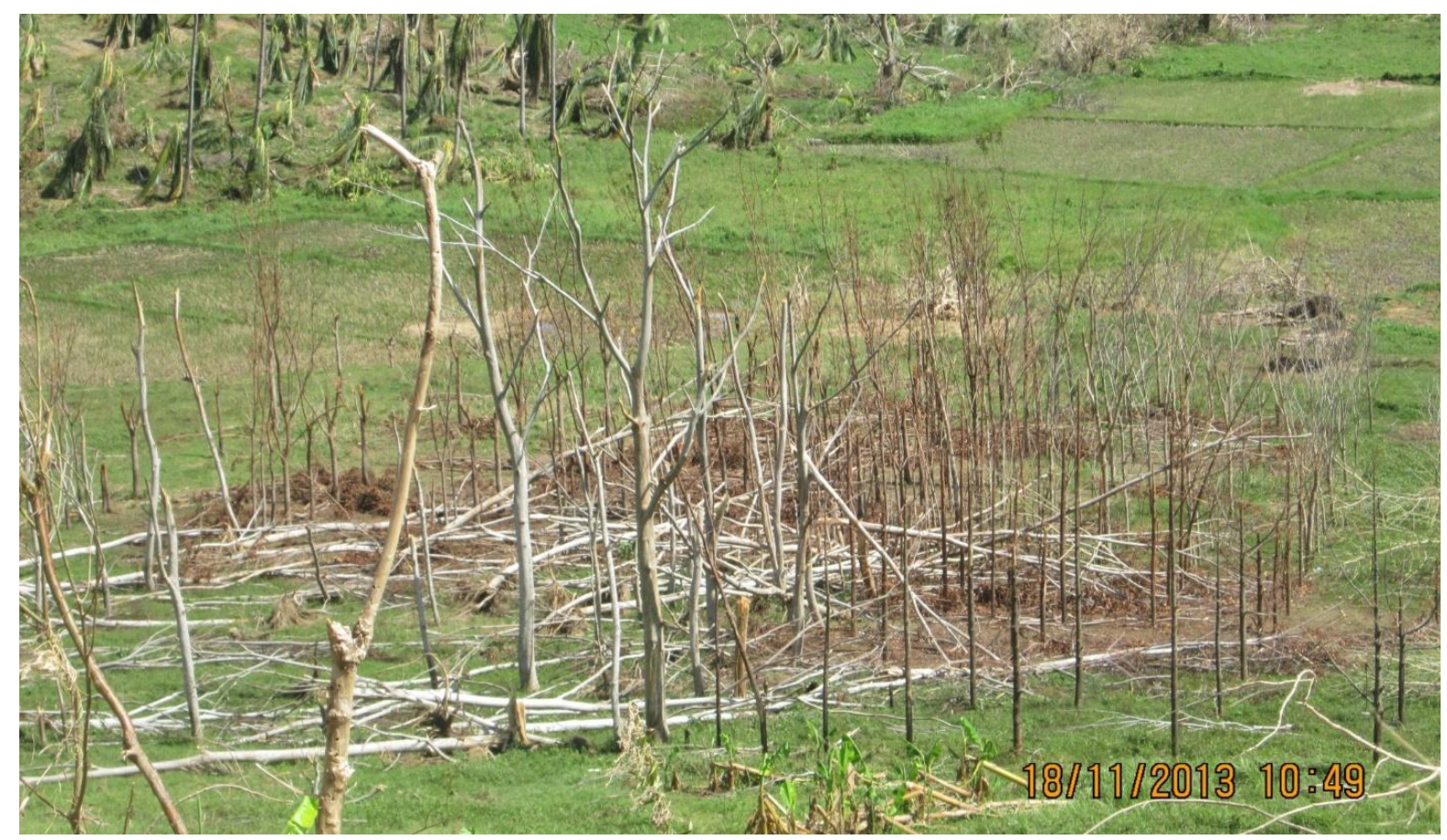

Figure 5. Variable spacing trial, ten days after the eye of Typhoon Haiyan passed directly over the plot, showing the complete defoliation of all species, and stem breakage of many Falcata trees.

Whilst Typhoon Yolanda/Haiyan caused complete defoliation and some destruction of this trial (Fig. 5), most trees have recovered surprisingly well (Fig. 6, from 2017, 4 years after the typhoon). This trial was intended primarily to reveal aspects of interspecific competition in mixed plantings, but it also contributed other interesting observations on the performance of these species. The trial demonstrated considerable differences in crown architecture, stem straightness and other species traits, as well as in understorey vegetation (Fig. 7) and in wind firmness (Fig. 5). This paper addresses a statistical analysis of competition, but the role of visual impressions gained from field visits should not be underestimated, especially for extension workers and smallholders. Figures 6 and 7 give an indication of stand structure and stem characteristics, but a walk through these plots is a memorable discussion-starter for most visitors, and the role of such demonstration plots should not be understated. 


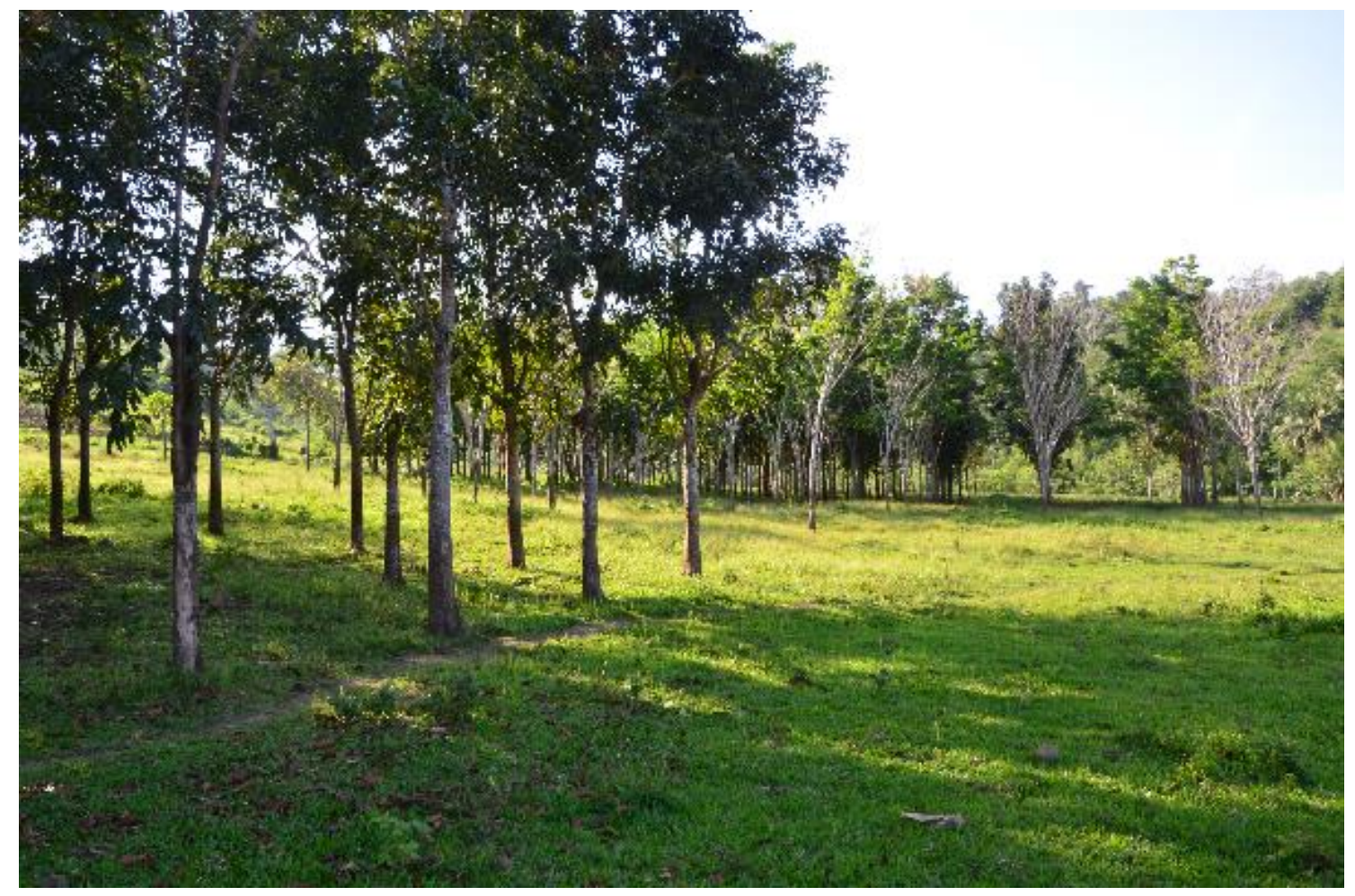

Figure 6: Good recovery of the trees in the trial in 2017 - foreground shows pure Mahogany ( $S$. macrophylla) in the variable composition plot; background shows the variable spacing plot.

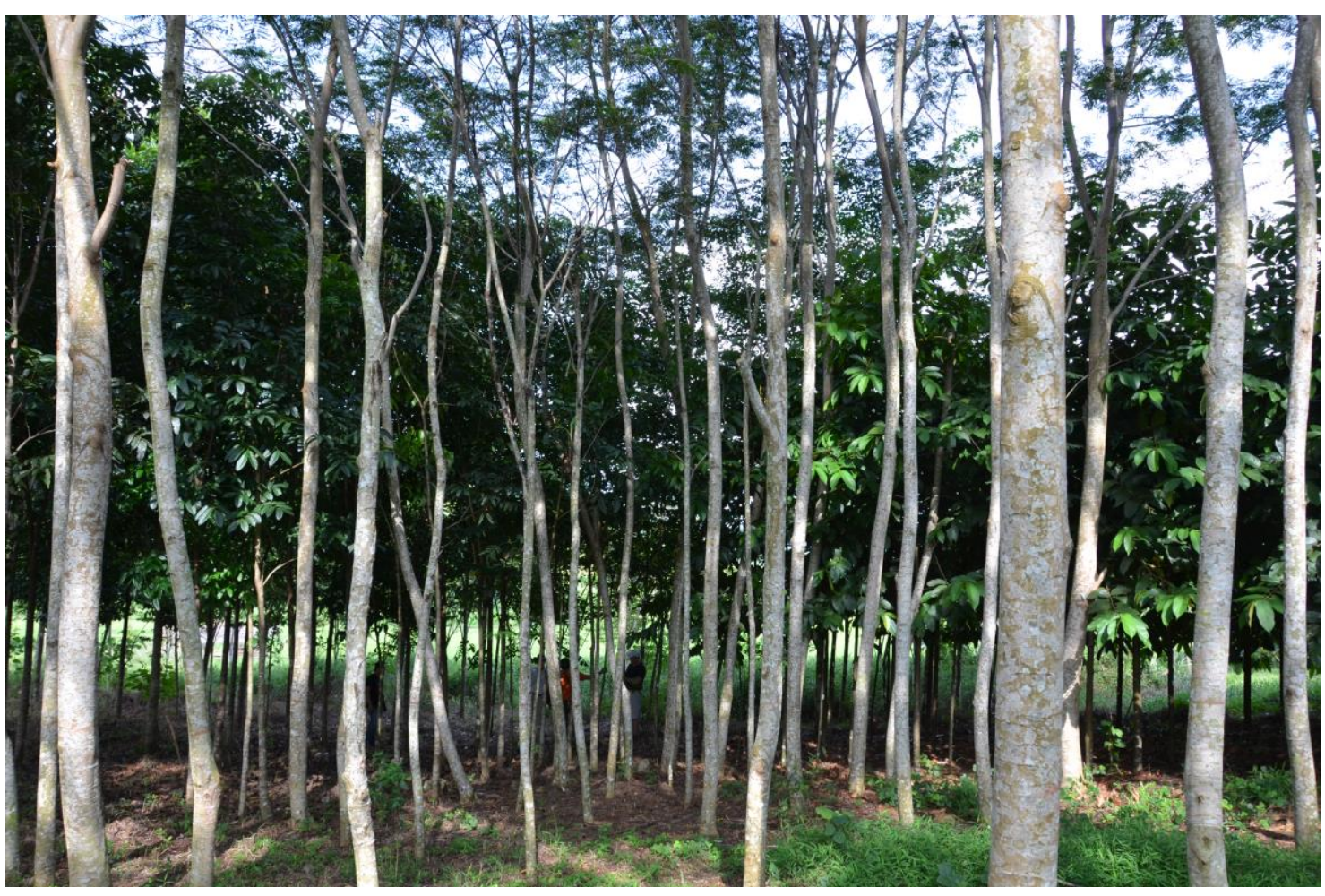

Figure 7. The variable spacing plot at 5 years old (July 2012) showing differences in stem characteristics. Falcata ( $P$. falcataria) is in the foreground, with Mahogany (S. macrophylla) to the left rear and Mayapis (S. palosapis) in the right rear. Note differences in stem form, branching habit, understorey vegetation. 
Our results are drawn from an analysis somewhat akin to data mining, with few assumptions other than the well-established presumption that competition should reduce growth (Assmann 1961). Thus it is useful to compare our empirical finding with published observations of these species (Table 4), which tend to be consistent with the empirical data presented in Table 3.

Table 4. Species characteristics ascertained from published literature.

\begin{tabular}{|l|l|l|l|l|}
\hline Niche & $\begin{array}{l}\text { Falcata } \\
\text { Paraserianthes } \\
\text { falcataria }\end{array}$ & $\begin{array}{l}\text { Mahogany } \\
\text { Swietenia } \\
\text { macrophylla }\end{array}$ & $\begin{array}{l}\text { Narra } \\
\text { Pterocarpus } \\
\text { indicus }\end{array}$ & $\begin{array}{l}\text { Mayapis } \\
\text { Shorea } \\
\text { palosapis }\end{array}$ \\
\hline $\begin{array}{l}\text { Pioneer (Krisnawati } 2011 \text {, Otsamo } \\
\text { et al 1997) }\end{array}$ & $\begin{array}{l}\text { Light-demanding } \\
\text { climax (Whitmore } \\
\text { 1998); Pioneer } \\
\text { (Snook \& } \\
\text { Negreros-Castillo } \\
\text { 2004) }\end{array}$ & $\begin{array}{l}\text { Pioneer (Lok } \\
\text { 2011) }\end{array}$ & $\begin{array}{l}\text { Climax (Swaine \& } \\
\text { Whitmore 1988) }\end{array}$ \\
\hline Exotic/Native & Exotic & Exotic & Native & Native \\
\hline $\begin{array}{l}\text { Planted/ } \\
\text { Regenerated }\end{array}$ & $\begin{array}{l}\text { Widely planted } \\
\text { (Krisnawati } \text { et al } \\
\text { 2011) }\end{array}$ & $\begin{array}{l}\text { Widely planted } \\
\text { (Krisnawati } \text { } \text { al al } \\
\text { 2011b) }\end{array}$ & $\begin{array}{l}\text { Widely planted } \\
\text { (Lok 2011) }\end{array}$ & $\begin{array}{l}\text { Potential for plantations } \\
\text { (Bullecer \& Socorin } \\
\text { 2013) }\end{array}$ \\
\hline Establishment & $\begin{array}{l}\text { Light-demanding } \\
\text { (Otsamo } \text { et al 1996) }\end{array}$ & $\begin{array}{l}\text { Light demanding } \\
\text { (Brown } \text { et al } \\
\text { 2003) }\end{array}$ & $\begin{array}{l}\text { Adaptable } \\
\text { (Thompson } \\
\text { 2006) }\end{array}$ & $\begin{array}{l}\text { Shade needed (Gregorio } \\
\text { et al 2012) }\end{array}$ \\
\hline Growth rate & $\begin{array}{l}\text { Rapid (Krisnawati } \\
\text { et al 2011a) }\end{array}$ & $\begin{array}{l}\text { Rapid (Krisnawati } \\
\text { et al 2011b) }\end{array}$ & $\begin{array}{l}\text { Rapid } \\
\text { (Thompson } \\
\text { 2006) }\end{array}$ & $\begin{array}{l}\text { Rapid (Bullecer \& } \\
\text { Socorin 2013) }\end{array}$ \\
\hline $\begin{array}{l}\text { Weed } \\
\text { suppression }\end{array}$ & $\begin{array}{l}\text { Casts light shade } \\
\text { (Krisnawati } \text { et al } \\
\text { 2011a) }\end{array}$ & - & $\begin{array}{l}\text { Casts heavy } \\
\text { shade } \\
\text { (Thompson } \\
\text { 2006) }\end{array}$ & - \\
\hline $\begin{array}{l}\text { Use as nurse } \\
\text { crop }\end{array}$ & $\begin{array}{l}\text { Suitable (Kamo } \text { et } \\
\text { al 2009; Lok 2011) }\end{array}$ & - & - & - \\
\hline Weed potential & $\begin{array}{l}\text { Invasive (Hughes } \text { et } \\
\text { al 2011) }\end{array}$ & - & - & - \\
\hline
\end{tabular}

The relationship fitted to our data (Equation 1, Table 1) was intended to reveal competition trends, not to make predictions, but a prediction offers a demanding test of the equation, particularly as it was derived from annualized estimates based on observations over a period less than 5 years (7/2008 to 4/2013). Figure 8 represents such a prediction for what the stand may have looked like at age 10 , assuming that all seedlings were $1 \mathrm{~cm}$ diameter at planting, and that all survived and avoided breakage. Typhoon damage to the field site means that this prediction cannot be formally tested, but the prediction seems plausible, and appears consistent with casual field observations (Figure 6). 


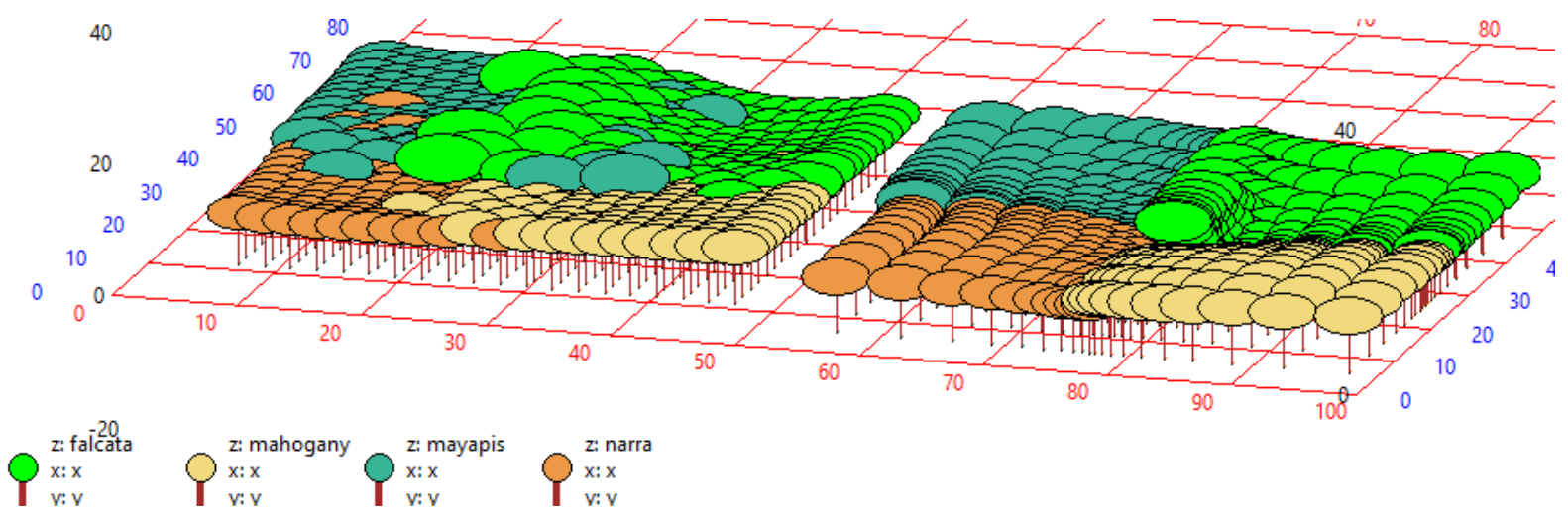

Figure 8. Prediction of stand development at age 10 (assuming no mortality). Species-specific responses to competition are evident.

At the final measure in 2013, the plots exhibited a relatively high correlation ( $r=-0.29)$ between tree size and competition that may have contributed to the issues highlighted in Figures $5 \& 6$. This is not surprising, as it is expected that the trees with the least competition will grow to be the largest, whilst those with the most competition grow more slowly, especially in the variable spacing plot. However, this correlation can be reduced easily by modest thinning in the variable spacing plot. Simulations show that the removal of two rows ( 9 and 12, near the centre of the 20-row plot) and two columns restores orthogonality (correlation $r=-0.03$ ). There is little benefit in further thinning, as the most effective additional option (removal of rows 5 and 15) provides modest improvement $(r=-0.01)$. However, the correlation between diameter and competition of Falcata stems remains rather high ( $r=-0.39)$ and some additional thinning in row 8 may have improved predictions for Falcata $(r=-0.19)$. Had the trial not suffered typhoon damage, it would have been desirable to thin rows 9 and 12 of the variable spacing plot to provide greater insights into tree growth, both for statistical efficiency and for demonstration purposes (Figure 9).
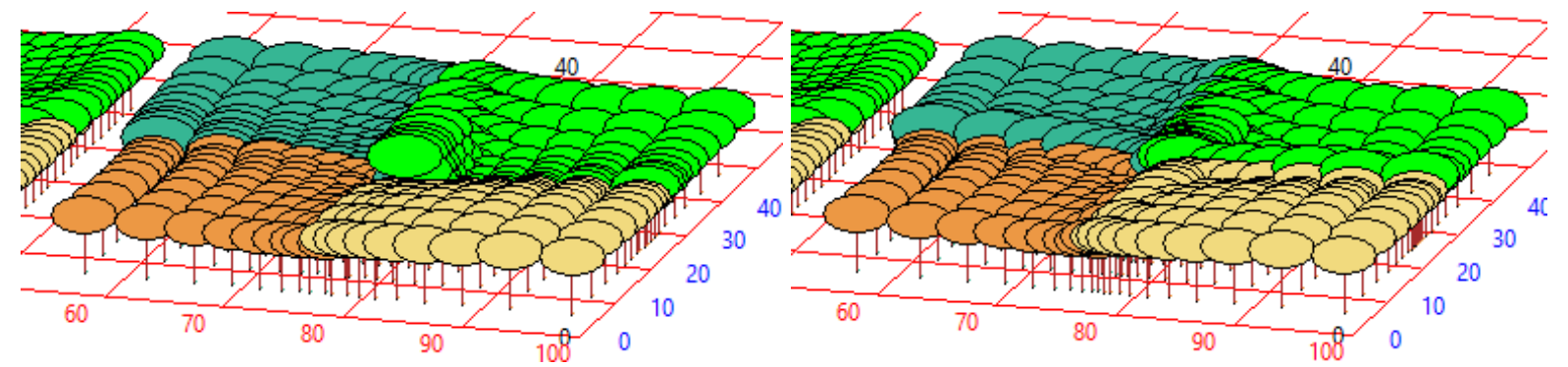

Figure 9. Prediction of the 5-year growth response to age 10, without (left) and with (right) thinning at age 5 of two rows in the variable spacing plot. The anticipated growth response is evident, but cannot be tested in the current trial.

\section{Conclusions}

Our findings suggest that contrary to some published findings (e.g., Chamagne et al 2017), the implications for tree growth of species diversity are not uniformly beneficial and are context dependent. It is clear from our findings that species vary widely in their interactions with potential competitors. 
Mayapis (S. palosapis) is a premium species that exhibits growth trends desirable in polycultures and is recommended as a candidate for further plantation establishment and reforestation efforts in the Philippines.

This experiment design proved to be an efficient way to test species interactions of four species and gain insights into competitive interactions within five years of planting. It is recommended that in any future plantings of this experimental design, the correlation between tree size and competition be monitored, and that a modest thinning (such as Figure 9) be considered when this correlation becomes high. This will enable stronger inferences about future growth patterns.

\section{References}

Assmann E (1961) Waldertragskunde. BLV, Munich.

Becker RA, Cleveland, WS (1987) Brushing scatterplots. Technometrics 29(2):127-142.

Bertalanffy Lv (1949) Problems of organic growth. Nature 163:156-158.

Botkin DB, Janak JF, Wallis JR (1972) Some ecological consequences of a computer model of forest growth. Journal of Ecology 60(3):849-872.

Box GE, Cox DR (1964) An analysis of transformations. Journal of the Royal Statistical Society: Series B (Methodological), 26(2), 211-243.

Brown N, Jennings S, Clements T (2003) The ecology, silviculture and biogeography of mahogany (Swietenia macrophylla): a critical review of the evidence. Perspectives in Plant Ecology, Evolution and Systematics 6:37-49.

Chechina M, Hamann A. (2015) Choosing species for reforestation in diverse forest communities: Social preference versus ecological suitability. Ecosphere 6(11):240

Bullecer R, Socorin L (2013) Growth performance of planted indigenous trees 12 years from establishment. International Journal of Environmental and Rural Development, 1(4), 118-123.

Chamagne J, Tanadini M, Frank D, Matuta R, Paine CET, Philipson CD, Svátek M, Turnbull LA, Volařík D, Hector A (2017) Forest diversity promotes individual tree growth in central European forest stands. Journal of Applied Ecology 54: 71-79.

Cook RD, Weisberg S (1999). Applied regression including computing and graphics (Vol. 488). John Wiley \& Sons.

Ek AR, Monserud RA (1974) Trials with program FOREST: growth and reproduction simulation for mixed species even- or uneven-aged forest stands. In J Fries (ed.) Growth Models for Tree and Stand Simulation. Proc. IUFRO Working Party S4.01-4 meetings, 1973. Dep. For. Yield Res., Royal Coll. For., Stockholm. Res. Note 30, pp. 56-69.

Forrester DI, Bauhus J, Cowie A, Vanclay JK (2006) Mixed-species plantations of Eucalyptus with nitrogen fixing trees: a review. Forest Ecology and Management 233:211-230. http://dx.doi.org/10.1016/j.foreco.2006.05.012

Forrester DI, Benneter A, Bouriaud O, Bauhus J (2017) Diversity and competition influence tree allometric relationships - developing functions for mixed-species forests. Journal of Ecology 105 : 761-774.

Goltiano H, Gregorio N, Pasa A, Herbohn J, Tripoli R, Valenzona J (2021) The effect of the implementation of the National Greening Program on the socioeconomic status of smallholders in Caibiran, Biliran, Philippines. Small-scale Forestry 1-20. https://doi.org/10.1007/s11842-02109482-9

Gregorio NO, Herbohn JL, Vanclay JK (2009) Establishing field trials to promote smallholder forestry in Leyte, The Philippines. In SR Harrison, A Bosch, J Herbohn, E Mangaoang (eds) ASEM/2003/052 Improving Financial Returns to Smallholder Tree Farmers in the Philippines End-of-Project Workshop held in Ormoc City, the Philippines, 11-12 February 2009. pp. 75-82.

Gregorio NO, Herbohn JL, Vanclay JK (2012) Developing establishment guidelines for Shorea palosapis in smallholder plantings in the Philippines. International Forestry Review 14(4): 492-501. http://dx.doi.org/10.1505/146554812804715856 
Gregorio N, Herbohn J, Harrison S, Smith C (2015) A systems approach to improving the quality of tree seedlings for agroforestry, tree farming and reforestation in the Philippines. Land Use Policy 47:29-41. https://doi.org/10.1016/j.landusepol.2015.03.009

Gregorio N, Herbohn J, Harrison S, Pasa A, Ferraren A (2017) Regulating the Quality of Seedlings for Forest Restoration: Lessons from the National Greening Program in the Philippines. Small-scale Forestry 16: 83-102. https://doi.org/ 10.1007/s11842-016-9344-z

Gregorio N, Herbohn J, Tripoli R, Pasa A (2020). A local initiative to achieve global forest and landscape restoration challenge-Lessons learned from a community-based forest restoration project in Biliran province, Philippines. Forests 11(4), 475.

Herbohn J, Gregorio N, Vanclay J (2009) Rationale and key research questions addressed by field trails established as part of the ACIAR Smallholder Tree Farmer Project. In S Harrison, A Bosch, J Herbohn, E Mangaoang (eds) ASEM/2003/052 Improving Financial Returns to Smallholder Tree Farmers in the Philippines End-of-Project Workshop held in Ormoc City, the Philippines, 11-12 February 2009. pp. 67-74.

Herbohn J, Vanclay J, Nguyen H, Le HD, Baynes J, Harrison SR, Cedamon E, Smith C, Firn J, Gregorio NO, Mangaoang E (2014). Inventory procedures for smallholder and community woodlots in the Philippines: Methods, initial findings and insights. Small-Scale Forestry 13:79-100.

Kamo K, Inagaki M, Abe H, Jamalung L, Lapongan J (2009) Choice of Suitable Nurse Tree Species for Rehabilitating Degraded Tropical Land. Pp.32-38 in T Gotoh, Y Yokota (eds) Development of Agroforestry Technology for the Rehabilitation of Tropical Forests, JIRCAS Working Report 60. ISSN 1341-710X.

Kelty MJ (2006) The role of species mixtures in plantation forestry. Forest Ecology and Management, 233(2-3), 195-204.

Krisnawati H, Varis E, Kallio M, Kanninen M (2011a) Paraserianthes falcataria (L.) Nielsen: Ecology, silviculture and productivity. CIFOR, Bogor, Indonesia.

Krisnawati H, Kallio M. Kanninen M (2011b) Swietenia macrophylla King: ecology, silviculture and productivity. CIFOR, Bogor, Indonesia.

Le HD, Smith C, Herbohn J, Nguyen H (2021) A Comparison of Growth, Structure and Diversity of Mixed Species and Monoculture Reforestation Systems in the Philippines. Journal of Sustainable Forestry 40(4):401-430.

Lui CLC, Kuchma O, Krutovsky KV (2018) Mixed-species versus monocultures in plantation forestry: Development, benefits, ecosystem services and perspectives for the future. Global Ecology and Conservation 15:e0419.

Lok EH (2011) Nutrition and nitrogen-fixation in Malaysian Pterocarpus indicus Willd. PhD Thesis, Murdoch University.

Mansfield ER, Helms BP (1982) Detecting multicollinearity. The American Statistician 36(3a):158-160.

Manson D, Schmidt S, Bristow M, Erskine PD, Vanclay JK, Lincoln D (2013) Species-site matching in mixed species plantations of native trees in tropical Australia. Agroforestry Systems 87:233-250. http://dx.doi.org/10.1007/s10457-012-9538-0

Nichols JD, Bristow M, Vanclay JK (2006) Mixed-species plantations: prospects and challenges. Forest Ecology and Management 233(2-3), 383-390. http://dx.doi.org/10.1016/j.foreco.2006.07.018

Nguyen H, Herbohn J, Firn J, Lamb D (2012) Biodiversity-production relationships in small-scale mixedspecies plantations using native species in Leyte Province, Philippines. Forest Ecology and Management 274:81-90

Nguyen H, Lamb D, Herbohn J, Firn J (2014a) Designing mixed species tree plantations for the tropics: balancing ecological attributes of species with landholder preferences in the Philippines. PLoS One 9(4), e95267. https://doi.org/10.1371/journal.pone.0095267

Nguyen H., Firn J, Lamb D, Herbohn J (2014b) Wood density: A tool to find complementary species for the design of mixed species plantations. Forest Ecology and Management 334:106-113.

Nguyen H, Herbohn J, Clendenning J, Lamb D, Dressler W, Vanclay JK, Firn J (2015) What is the available evidence concerning relative performance of different designs of mixed-species plantings for smallholder and community forestry in the tropics? Environmental Evidence 4:15. http://dx.doi.org/10.1186/s13750-015-0041-8 
Nguyen H, Vanclay J, Herbohn J, Firn J (2016) Understanding drivers of tree growth, mortality and harvest preferences in species-rich plantations for smallholders and communities. PLOS One 11(10), e0164957. https://doi.org/10.1371/journal.pone.0164957

Otsamo, R, Ådjers G, Hadi TS, Kuusipalo J, Otsamo A (1996) Early performance of 12 shade tolerant tree species interplanted with Paraserianthes falcataria on Imperata cylindrica grassland. Journal of Tropical Forest Science 8:381-394.

Otsamo R, Adjers AG, Hadi TS, Kuusipalo J, Vuokko R (1997) Evaluation of reforestation potential of 83 tree species planted on Imperata cylindrica dominated grassland - A case study from South Kalimantan, Indonesia. New Forests 14: 127-143.

Potvin C, Dutilleul P (2009) Neighborhood effects and size-asymmetric competition in a tree plantation varying in diversity. Ecology, 90(2):321-327.

Snook LK, Negreros-Castillo P (2004) Regenerating mahogany (Swietenia macrophylla King) on clearings in Mexico's Maya forest: the effects of clearing method and cleaning on seedling survival and growth. Forest Ecology and Management 189:143-160

Swaine, MD, Whitmore TC (1988) On the definition of ecological species groups in tropical rain forests. Vegetatio 75: 81-86.

Thomson LA(2006) Pterocarpus indicus (narra). Species Profiles for Pacific Island Agroforestry. https://agroforestry.org/images/pdfs/Pterocarpus-narra.pdf

Trogisch S, Liu X, Rutten G, Xue K, Bauhus J, Brose U, Bu W, Cesarz S, Chesters D, Connolly J, Cui X, Eisenhauer N, Guo L, Haider S, Härdtle W, Kunz M, Liu L, Ma Z, Neumann S, Sang W, Schuldt A, Tang Z, van Dam NM, von Oheimb G, Wang MQ, Wang S, Weinhold A, Wirth C, Wubet T, Xu X, Yang B, Zhang N, Zhu CD, Ma K, Wang Y, Bruelheide H (2021) The significance of treetree interactions for forest ecosystem functioning. Basic and Applied Ecology, https://doi.org/10.1016/j.baae.2021.02.003

Vanclay JK (1991) Data requirements for developing growth models for tropical moist forests. Commonwealth Forestry Review 70:248-271. https://www.jstor.org/stable/42606811

Vanclay JK (1994) Modelling Forest Growth and Yield: Applications to Mixed Tropical Forests. CAB International, Wallingford, UK, 312 p. ISBN: 0-85198-913-6

Vanclay JK (2006a) Experiment designs to evaluate inter- and intra-specific interactions in mixed plantings of forest trees. Forest Ecology and Management 233:366-374. http://dx.doi.org/10.1016/j.foreco.2006.05.034

Vanclay JK (2006b) Spatially-explicit competition indices and the analysis of mixed-species plantings with the Simile modelling environment. Forest Ecology and Management 233:295-302. http://dx.doi.org/10.1016/j.foreco.2006.05.020

Vanclay JK (2010) Robust relationships for simple plantation growth models based on sparse data. Forest Ecology and Management 259:1050-1054. http://dx.doi.org/10.1016/j.foreco.2009.12.026

Vanclay JK (2017) Robust Models for Smallholder Forests. Indian Forester 143(9), 852-855.

Vanclay JK, Lamb D, Erskine P, Cameron DM (2013) Spatially-explicit competition in a mixed planting of Araucaria cunninghamii and Flindersia brayleyana. Annals of Forest Science 70:611-619. http://dx.doi.org/10.1007/s13595-013-0304-x

Vanclay JK, Skovsgaard JP, Hansen CP (1995) Assessing the quality of permanent sample plot databases for growth modelling in forest plantations. Forest Ecology and Management 71:177-186. http://dx.doi.org/10.1016/0378-1127(94)06097-3

Veridiano RK, Schroder JM, Come R, Baldos A, Gunter S 2020. Towards Forest Landscape Restoration Programs in the Philippines: Evidence from logged forests and mixed-species plantations. Environments 7(3):20. https://doi.org/10.3390/environments7030020

Whitmore TC (1998) An Introduction to Tropical Rain Forests. Oxford University Press, Oxford. Zeide B (1993) Analysis of Growth Equations. Forest Science 39(3):594-616. 


\section{Declarations}

Ethics approval and consent to participate

Not applicable

\section{Consent for publication}

Not applicable

Availability of data and material

The dataset used in this study are available from the corresponding author on request.

\section{Competing interests}

The authors declare that they have no competing interests.

\section{Funding}

This work was funded in part by ACIAR projects ASEM/2003/52, ASEM/2006/091 and ASEM/2010/050.

\section{Authors' contributions}

JH secured the funding; NG supervised the fieldwork; JV conducted the analysis; all authors contributed to writing this paper.

\section{Acknowledgements}

Not applicable 